\title{
CONCEPT OF QUALITY EDUCATION AKHLAKUL KARIMAH BASED SYEKH NAWAWI'S PERSPECTIVE
}

\author{
Asep Nuhdi \\ Program Studi Pendidikan Agama Islam IAI Nasional Laa Roiba Bogor, Indonesia. \\ Email: asepnuhdi@gmail.com \\ DOI: https://doi.org/10.29313/tjpi.v9i1.6219 \\ Submitted: May 31th, 2020. Approved: June 29th, 2020. Published: June 29th, 2020
}

\begin{abstract}
The family is the initial foundation for the formation of the power of the ummah and human civilization. The research method used is Library Research using library data related to the problem being studied, in the form of the AlQuran, Tasir Al Quran, the Hadith Book, the books of Syekh Nawawi al Bantani and books related to family education, journals and others. etc. The approach that the author uses is qualitative, which is related to literature in the form of books, books and so on by not using numbers. The research objective is to find out how the concept of Islamic family education is based on the classical books by Sheikh Nawawi Al Bantani, who is a scholar who is the reference for scholars in Indonesia. The conclusion of this study is that which is included in the realm of family education thought according to Sheikh Nawawi Al Bantani, including the purpose of family education, namely teaching good morals, education for children is very important because parents as the first and foremost educators in the family will determine the character, attitude and behavior of their children. in the future, and the education of wives in the family provides teachings on Islamic sharia and educate them about karma, namely teaching good morals and for Sheikh Nawawi the person whose torment is the most severe on the Day of Judgment because he neglects his family's education.
\end{abstract}

Keywords: Educational Concept, Akblakul Kariman, An-Nawawi.

\begin{abstract}
Abstrak
Keluarga merupakan pondasi awal bagi terbentuknya kekuatan ummat dan peradaban manusia. Adapun metode penelitian yang digunakan adalah Library Research menggunakan data pustaka yang berkaitan dengan masalab yang sedang dikaji, berupa AlQuran, Tasir Al Quran, Kitab Hadis, Kitab-kitab Syekh Nawawi al Bantani dan buku-buku yang berkaitan dengan pendidikan keluarga, jurnal dan lain sebagainya. Pendekatan yang penulis gunakan adalab kualitatifyaitu yang berkaitan dengan literature-literatur berupa buku, kitab dan lain sebagainya dengan tidak menggunakan angka-angka. Tujuan penelitian untuk mengetabui bagaimana konsep pemikiran pendidikan keluarga islam dengan berdasar kitab kitab klasik. karya syekh Nawawi Al Bantani yang merupakan ulama yang menjadi rujukan para ulama di Indonesia. Kesimpulan dari penelitian ini adalah yang termasuk kedalam ranah pemikiran pendidikan keluarga menurut syekh Nawawi Al Bantani diantaranya tujuan pendidikan keluarga yakni mengajarkan akblak yang baik, pendidikan terhadap anak sangat penting karena orang tua sebagai pendidik pertama dan utama dalam keluarga akan menentukan karakter, sikap dan perilaku anaknya di masa mendatang,dan pendidikan istri dalam keluarga memberikan pengajaran tentang syariah Islam dan didiklah mereka tata karma yakni mengajarkan akblak. yang baik dan bagi Syekh Nawawi orang yang paling berat siksaannya pada hari kiamat itu sebab menelantarkan pendidikan keluarganya.
\end{abstract}

Kata Kunci: Konsep Pendidikan, Akhlakul Kariman, An-Nawawi. 


\section{PENDAHULUAN}

Dalam Islam Pendidikan memiliki kedudukan yang tinggi. $\mathrm{Hal}$ ini dibuktikan dengan disebutkannya konsep pendidikan dalam Al Quran dan Al Hadis berulang kali Misalnya dalam wahyu pertama QS Al Alaq 1-5 yang disampaikan kepada Nabi SAW yang menyuruhnya membaca dalam keadaan yang tidak bisa membaca. Kondisi ini menyiratkan adanya konsep proses belajar mengajar antara yang lebih tahu (Malaikat jibril sebagai penyampai wahyu) kepada Nabi Muhammad SAW yang belum tahu bagaimana membacanya. Di samping itu, wahyu pertama ini juga mengandung ajakan atau suruhan belajar menganai ALLAH SWT, memahami fenomena alam dan mengenali diri yang terangkum dalam prinsip-prinsip aqidah, ilmu dan amal. Disamping itu, Hadis riwayat Bukhari Muslim yang menyuruh manusia unntuk "Belajarlah semenjak dari buaian hingga liang lahat. Disini manusia disuruh untuk tidak hentihentinya menimba ilmu dan mengenyam pendidikan sedini mungkin hingga ajal menjelang. Hal ini menunjukan pendidikan merupakan suatu proses yang harus dilalui manusia untuk dapat mengembangkan dirinya sepenuhnya.

Bagi orang yang tidak menjadikan tauhid sebagai dasar pendidikan dalam arti ia tidak memiliki pegangan hidup yang benar, semakin lama ia memperdalam ilmu, semakin hilang tempat rasa berpijak, apa yang kemarin masih benar, sekarang sudah tak betul lagi. Apa yang betul sekarang besok sudah salah pula. (Thohir \& Natsir, 1999, hal. 97).

Agar proses pendidikan dapat berjalan sesuai yang diharapkan maka pendidikan, pengajaran dan metodenya harus diambil dari aturan-aturan dan nilainilai tersebut sehingga menjadi pemandu program pendidikan Islam yang sukses, dapat menciptakan generasi muda yang berpotensi dan berkepribadian yang Islami menurut Hasan Langgulung bahwa untuk mencapai itu semua, sejak dini anak harus dibekali keimanan dan ketaqwaan kepada Allah SWT. Setelah iman dan taqwa bersemayam dalam hati anak maka perilaku yang ditampilkan akan mempengaruhi penyesuaian diri dengan dirinya maupun dengan masyarakat sehingga membawa kepada ketenangan hidup, ketentraman jiwa, maupun kebahagian batin, (Langgulung, 2004, hal. 82). Oleh karena itu untuk mengantarkan anak pada kematangan pribadinya maka kajian Pemikiran Pendidikan Keluarga Menurut Syekh Nawawi dalam karyakarya Syekh Nawawi seperti Kitab Uqudulujjain, Tanqih Al Qaul dan Maraqi Al Ubudiyyah ini sangat signifikan jika dipakai sebagai acuan dalam upaya mencapai keberhasilan pendidikan, terutama pendidikan adab kepribadian.

Salah satu lembaga pendidikan yang penting ialah pendidikan keluarga. Keluarga memiliki dampak yang besar dalam pembentukan perilaku dan pengembangan vitalitas dan ketenangan dalam keluarga. Melalui keluarga, anakanak mendapatkan bahasa, nilai dan norma serta kecenderungan mereka. Tanggung jawab pendidikan dalam keluarga menurut Syekh Nawawi tidak hanya mengirimkan anak kepada guru, tetapi juga tentang biaya pendidikannya. Apabila keluarga tidak mampu, maka biaya pendidikan dibebankan kepada pemerintah, sedangkan apabila pemerintah tidak mampu maka tanggung jawabnya dibebankan kepada orangorang yang mampu. (Siregar, 2007, hal. 5).

Syekh Nawawi al-Jawi (alBantani) adalah salah satu tokoh intelektual muslim yang menjadi kebanggan umat Islam Indonesia. Kebanggan kepadanya agaknya tidaklah berlebihan karena keberadaannya telah memberikan kontribusi yang besar terhadap dunia intelektual dan citra Islam 
di mata dunia Islam. Kepakaran beliau di berbagai disiplin ilmu keislman diakui dunia Islam.

Bahkan para ulama Mesir menjulukinya dengan "Sayyid Ulama alHijaz" (Pemimpin Ulama Hijaz). Hal tersebut dapat kita buktikan dengan banyaknya karya ilmiah dalam berbagai disiplin ilmu yang beliau tulis. Keagungan yang didaptkan Syekh Nawawi berkat ilmu dan semangat untuk menyebarkan ilmu-ilmu agama Islam. Semangat pemikiran tehadap dunia keilmuan Islam ini mengantarkan Syekh Nawawi sebagai ulama Indonesia membanggakan dan menjadi salah satu tokoh utama dalam penyebaran ilmu-ilmu Islam (Chaidar, 1999, hal. 6). Pemikiran Syekh Nawawi mengenai keluarga dan pentingnya pembentukan kelurga Islami yang akan melahirkan generasi Islam yakni anak anak yang memiliki pendidikan adab tercermin dalam karya karya beliau dan pendapat pendapat beliau tercurah dalam kitab Uqudulljain, Maraqi al Ubudiyyah, Tanqih al Qaul dan Tafsir Al Munir dan kitab kitab karya Syekh Nawawi banyak dikaji di Pesantren pensantren di Indonesia.

Tujuan pendidikan bukanlah suatu benda yang berbentuk tetap dan statis tetapi tujuannya itu merupakan keseluruhan dari kepribadian seseorang yang berkenaan dengan seluruh aspek kehidupannya. Seperti dikatakan oleh (Langgulung, 2004), berbicara tentang tujuan pendidikan tidak terlepas dari pembahasan tentang tujuan hidup manusia. Oleh karena itu Pendidikan hanyalah suatu alat yang digunakan manusia untuk memelihara kelanjutan hidupnya. Baik sebagai individu atau masyarakat.

Tujuan pendidikan tersebut tidak jauh berbeda dengan tujuan pendidikan yang ada dalam kitab karya Syekh Nawawi misalnya Maraqi al Ubudiyyah. Tujuan dalam kitab Maraqi al Ubudiyyah adalah upaya pembentukan adab dan kepribadian individu dan kepribadian social yang baik. Seperti contohnya taat kepada ALLAH SWT, meninggalkan maksiat, akan membentuk kepribadian individu yang baik. Sedangkan kepribadian social dengan menanamkan adab terhadap orang tua, guru dan teman.

Dalam Kitab Maraqi al Ubudiyyah Nawawi banyak menjelaskan akhlak mahmudah seperti contoh ketaatan. hal ini akan terwujud jika kita senatiasa patuh terhadap perintahperintah Allah baik yang wajib maupun yang Sunnah. Menghargai setiap orang yang memiliki kehormatan dan menghargai orang-orang yang patut dihargai seperti guru, orang tua dan teman. Kitab karya syekh Nawawi ini juga menjelaskan akhlak tercela yang harus ditinggalkan seperti conth meninggalakan maksiat karena jika maksiat merajalela di masyarakat, maka tidak bisa diharapkan terwujudnya keamanan dan kedamaian dalam kehidupan bersama.

Konsep pemikiran Syekh Nawawi dalam hal pendidikan bisa kita kaji dalam karyanya diantaranya Tafsir Munir. Term Hikamah menurut Syekh Nawawi al Bantani dalam kitabnya Tafsir Munir adalah petunjuk dari Allah untuk melakukan suatu pekerjaan yang didasari dengan Ilmu (Ilmu yang diamalkan, dana mal yang didasari dengan ilmu). Begitu juga dengan pembentukan keluarga yang islami Pemikiran Syekh Nawawi tertuang dalam Kitab Uqudulujain.

Sebagai seorang ulama, Syekh Nawawi terbilang yang sangat produktif mengarang kitab. Ia mulai menulis ketika sudah menetap di Makkah setelah tidak betah dengan Belanda sebagai pengabdian intelektual. Menurut beberapa orang yang meneliti karyakaryanya sekitar 115 buah kitab lahir dari tangannya. Namun adapula yang menyebutnya 99 buah kitab. yang terdiri dari berbagai disiplin ilmu agama. 
Namun menurut Burhanuddin. diantara beberapa pemerhati karya-karya Syekh Nawawi tidak ada kesepakatan mengenai jumlah buku yang ditulis Syekh Nawawi yang sebagian besar ditulis dalam Bahasa Arab.

Produktivitas Syekh Nawawi dalam menulis kitab memang hamperhampir tak terbendung. Seorang murid Nawawi Bernama Syekh Abdul Sattar al Dahlawi menceritakan salah satu keistimewaan Syekh Nawawi adalah kemampuannya mengarang kitab sambal mengajar. Ketika dia mengajar para murid-muridnya, ditengah-tengah itu pula beliau menuliskan karya-karyanya. Puluhan sampai ratusan kitab yang lahir dari tangannya itu juga terdiri dari beragam kajian dan pembahasan.

Menurut Brocklemen, karya Nawawi meliputi delapan cabang utama ilmu keislaman yakni Tafsir, Fikih, Ushuluddin, Tasawuf, Biografi Nabi, tata Bahasa arab dan retorika. Dalam bidang Tafsir seperti Tafsir Munir dalam bidang hadis kitab Tanqih al Qaul dalam bidang ushuluddin Fathul Majid, Qatr al Ghaits. Bidang Fikih ada kitab Maraqi al Ubudiyyah, Kasyifatus Saja, Nihayatuz Zain, Uqudulujjain. Dalam Bidanng Tasawuf kitab Mishbahuz Zalam. Dalam bidang. Biografi Nabi yakni Kitab al Dhurar al Bahiyyah.

Kitab Uqudulujjain merupakan salah satu karangan Syekh Nawawi dari beberapa kitab yang dikarangnya. Kitab Uqudulujjain sudah sangat terkenal di kalangan pesantren salafi yang akrab dengan sebutan kitab kuning. Kitab ini merupakan kitab yang diajarkan di Pesantren salafi. Kitab Uqudujjain ditulis pada tahun 1294 H. Dalam kitabnya Syekh Nawawi mengatakan bahwa kitab kecil ini penting bagi seseorang yang menginginkan keluarga yang sakinah berdasarkan Al Quran, Hadis dan sejarah para tokoh terdahulu dan juga pendapatpendapat pribadi yang terperinci pada empat pembahasan yakni Hak Istri atas suami, Hak suami atas istri, Keutamaan wshalat di rumah, Larangan bagi laki-laki melihat wanita lain dan sebaliknya.

Dari pemaparan memberikan pemahaman betapa siginifikannya pemikiran Syekh Nawawi dalam karyakaryanya (Maraqi al Ubudiyyah, Tafsir Munir, Uqudulujjain dan Taqih al Qaul) dalam pendidikan kelurga yaitu keluarga yang mempu dan tercipta keluarga yang islami karena Keluarga memiliki dampak yang besar dalam pembentukan perilaku dan pengembangan vitalitas dan ketenangan dalam keluarga. Melalui keluarga, anak-anak mendapatkan bahasa, nilai dan norma serta kecenderungan mereka. Tanggung jawab pendidikan dalam keluarga sehingga penting bagi suami mendidik istri dan anak-anaknya sesuai dengan ajaran islami. Istri merupakan sekolah pertama bagi anakanak dan anak-anak merupakah generasi penerus yang mereka semua harus dibekali dengan Ilmu (Ilmu yang diamalkan, dana mal yang didasari dengan ilmu). Dengan mempelajari dan menelaah pemikiran konsep pendidikan keluarga menurut syekh Nawawi semoga dapat membentuk generasi yang terbaik sesaui dengan konsep "Kuntum Khaira Ummah".

\section{PEMBAHASAN}

\section{Tujuan Pendidikan}

Di dalam paedagogik dikatan bahwa pendidikan seseorang atau pendidikan individual itu berlaku didalam keluarga, sedangkan pendidikan sosial atau pendidikan mekamsyrakatan adalah tugas dari perguruan atau pendidikan formal. Namun pada dasarnya pendidikan formal berfungsi sebagai faktor pendukung sedangkan pusat segala pendidikan adalag keluarga.

Keluarga merupakan akar bagi terbentuknya masyarakat, bangsa dan bahkan sebuah peradaban. Kesinambungan dalam masyarakat atau 
bangssa dapat dipengaruhi keseimbangan keluarga-keluarga yang menjadi anggotanya. Jika keseimbangan keluarga didalam sebuah masyarakat itu baik, akan baiklah masyarakat itu, sebaliknya jika keseimbangan masyarakat itu buruk, banyak hal yang diperoleh anak adan pelajaran tersebut adalah pelajaran pertama yang ia terima ia akan melekat dan menjadi dasar yang kuat saat akan menerima banyak hal/pelajaran di luar kelak (Salim, 2013, hal. 136).

Syekh Nawawi dalam karyanya kitab 'Uqud al Lujjayn menyampaikan bahwa manusia yang paling berat siksanya pada hari kiamat adalah sebab menelantarkan pendidikan keluarganya (Al-Bantani, n.d.-a, hal. 11). Dan Syekh Nawawi menafsirkan firman Allah SWT dalam surat al Tahrim (66) ayat 6 , menukil Ibn 'Abbas :

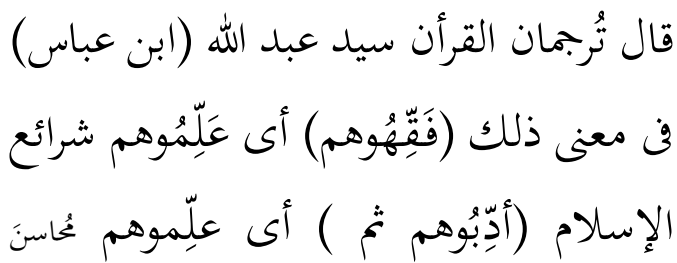

الأخلاقِ(Al-Bantani, n.d.-a, hal. 11)

Melihat penjelasan ini Syekh Nawawi menguraikan bahwa pendidikan yakni didiklah maksudnya ajarkan akhlaqakhlaq yang baik karena tujuan utama pendidikan adalah membentuk karakter anak didik. Tujuan pendidikan menurut Syekh Nawawi dapat kita lacak didalam سلالم الفضلاء

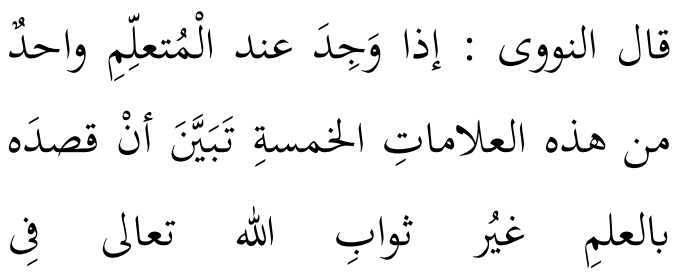

الأخرة (Nawawi, n.d., hal. 12)

Bahwasanya apabila dijumpai pada seorang pelajar salah satu dari lima tanda-tanda ini, maka jelas pasti bahwa tujuannya (menuntut) ilmu bukan (untuk meraih) ganjaran Allah SWT di akhirat melihat tujuan yang diuraikan oleh Syekh Nawawi bahwa apabila terdapat 5 tujuan dalam menuntut ilmu maka tujuan menuntut ilmu menjadi rusak maka seyogianya untuk menghindari dari lima tujuan tersebut yakni sebagai berikut :

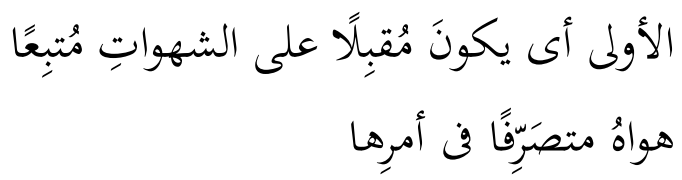

Yakni keadaan pelajar itu mengabulkan keinginan syahwat, lgi mengikuti hawa nafsunya, lagi diatur oleh perintah hawa nafsunya.

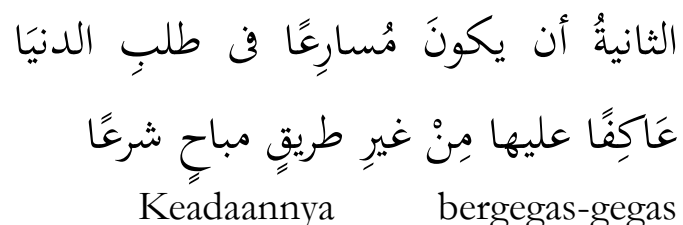
dalam mencari duniawi, berkonsentrasi mencari duniawi, tanpa melalui cara yanggg diperbolehkan oleh syari'at.

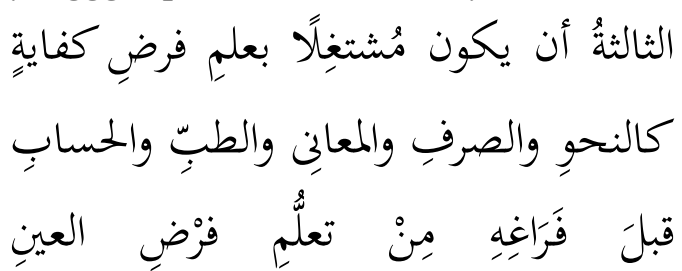

وعملِه (Nawawi, n.d., hal. 130)

Keadaannya menyibukkan diri dengan ilmu fardlu kifayah seperti nahwu, sharaf, ma'âni, kedokteran, matematika, sebelum ia menuntaskan mempelajari ilmu fardu 'ain dan mengamalkannya.

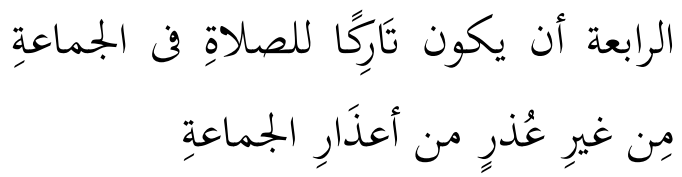

Keadaannya meninggalkan shalat jama'ah, tanpa satu pun udzur dari berbagai udzur shalat berjama'ah.

$$
\begin{aligned}
& \text { الخامسة أن يكون تاركا للرَّوَاتِبِ الْمُؤَّدة } \\
& \text { والسُنْنِ الْمؤكدةِ }
\end{aligned}
$$


(kesunahannya) dan sunnah-sunnah muakkad lainnya.

Selanjutnya Syekh Nawawi
mengutip pernyataan ulama
"Sesungguhnya aku lelah melihat masyarakat di zaman kita (sekarang), mareka tidak menuntut ilmu untuk diamalkan, melainkan demi membanggakan diri kepada temantemannya dan sebagai persiapan untuk menipu dan menzhalimi (Nawawi, n.d., hal. 130). Dari uraian singkat tersebut bahwa ada 5 hal yang dapat merusak tujuan utama bagi penuntut ilmu yakni syahwat, masalah diniawi, menyibukkan ilmu fardlu kifayah, meninggalkan shalat jama'ah, meninggalkan shalat sunnah rawatib dan jangan sampai bagi penuntut ilmu karena demi membanggakan dihadapan teman-temannya.

\section{Pendidikan Anak}

Syekh Nawawi dalam kitab Tanqih al Qaul al Hatsits, membuat satu bab tersendiri tentang hadits-hadits yang berkaitan dengan keutamaan mendidik anak (فضيلة تربية الأولاد). Sebagaimana sabda Nabi SAW :

$$
\begin{aligned}
& \text { قال النبي عليه الصالاة والسالام ما نَحَل والدُ } \\
& \text { ولدَه أفضلُ من أدبٍ حسنٍ }
\end{aligned}
$$

"Dan telah bersabda Nabi SAW: "Tidaklah memberi orang tua kepada anaknya akan sesuatu yang lebih utama dibandingkan pendidikan pekerti yang baik." (Al-Bantani, n.d.-b)

Penjelasan Syekh Nawawi, hadits diriwayatkan oleh Imam al Tirmidzi dan Imam al Hakim dari Sayyidina Amru ibn Said ibn al 'Ash. Maksudnya adalah tidaklah memberi orang tua kepada anaknya akan sesuatu pemberian yang lebih utama daripada pendidikan orang tuan dengan semacam teguran, ancaman dan memukul untuk berbuat kebaikan dan menjauhi hal-hal yang buruk.

Karena sesungguhnya pendidikan yang baik dapat mengangkat seorang budak hamba sahaya kepada derajat para raja (Terdapat dalam kitab Sunan at-Tirmidri, hadits ke 1959, dalam Musnad Imam Abmad Hadits ke 14856, dalam Jami'us shaghir juz 2 buruf mim (HR. al Tirmidzi) dan dalam Kitab Syubul Iman Imam Baibaqi juz. II hadits 399 hadits ke 8 , n.d.).

Pada hadits ini Syekh Nawawi menjelaskan bahwa pendidikan orang tua sangat penting bagi anak. Oleh karena itu setiap orang tua agar memberikan pendidikan kepada keluarga. Orang tua sebagai pendidik pertama dan utama dalam keluarga akan menentukan karakter, sikap dan prilaku anaknya dimasa mendatang.

Orang tua yang menyebabkan pula nak itu menjadi beriman atau kafir terhadap Allah SWT. Kewajiban orang tua sebagai pendidik banyak dinyatakan dalam berbagai sabda Rasulullah SAW (Rosyadi, 2014, hal. 55).

Selanjutnya Syekh Nawawi menyampaikan hadits Nabi :

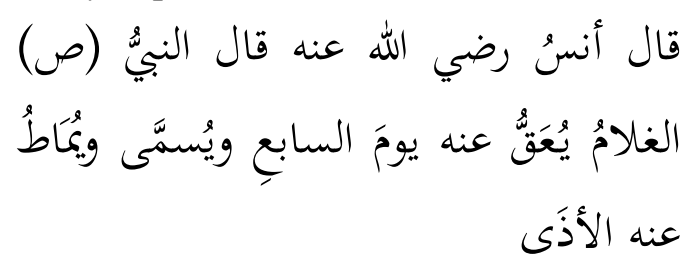

Telah berkata Sayyidina Anas ibn Malik RadiyAllahu 'anhu : "Telah bersabda Nabi SAW : "Anak itu di 'aqiqah dirinya pada hari ketujuh, diberi nama dan dihilangkan kotoran dari dirinya.

$$
\text { فإذا بَتَغَ ستَّ سِنينَ أدِبَ }
$$

Lalu apabila ia telah mencapai usia enam tahun, maka dididik.

$$
\text { فإذا بلغ تسعَ سنين عُِْلَ فِراشِه }
$$

Lalu apabila ia telah mencapai usia sembilan tahun, maka pisahkanlah tempat tidurnya.

$$
\text { فإذا بلغ ثلاتَّ عشرةَ سنةً ضُرِبَ على }
$$


Lalu apabila ia telah mencapai usia tiga belas tahun, maka ia dipukul atas (meninggalkan) shalat.

$$
\text { فإذا بلغ ستَّ عشرةَ سنةً زَوَّجَهُ أبوهُ }
$$

Lalu apabila ia telah mencapai usia enam belas tahun, maka ayahnya mengawinkannya.

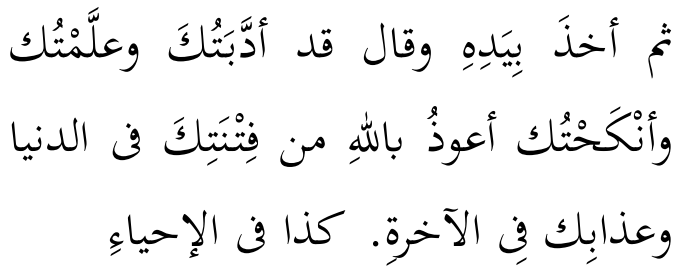

Kemudian si ayah memegang tangan anak itu sembari berkata : "Sungguh aku telah mendidik mu, mengajarimu dan menikahkanmu. Aku berlindung kepada Allah dari fitnah dirimu di dunia dan siksaan karena mu di akhirat". Demikianlah (disebutkan) di dalam kitab al Ihyầ'.

Keterangan diatas memberi pelajaran tentang tahapan usia belajar dan metode pembelajaran yang seharusnya dilakukan oleh orang tua terhadap anaknya demikian yang diungkapkan ole Syekh Nawawi mengutip di dalam kitab Ihyâ' dan kurikulum yang pertama adala shalat bakan sampai materi pernikahan.

Selanjutnya Syekh Nawawi mengutip hadits Nabi SAW:

$$
\begin{aligned}
& \text { قال النبي عليه الصالاة والسلامُ ما نحل بِفتح } \\
& \text { النولِ والحاءُ الْهُهملةِ (والدُ ولدَه أفضلُ من } \\
& \text { أدبٍ حسنِ }
\end{aligned}
$$

Dan telah bersabda Nabi SAW "Tidaklah memberi (kalimat nahalu) (orang tua kepada anaknya akan sesuatu yang lebih utama dibandingkan pendidikan pekerti yang baik"

$$
\text { بوراه الترمذئُ والحاكمُ عن عمروٍ ابنِ سعيدٍ }
$$

Hadits diriwayatkan oleh Imam at-Tirmidzi dan Imam Hakim dari sayyidina 'Amru ibn Sa'id ibn al-'Ash.

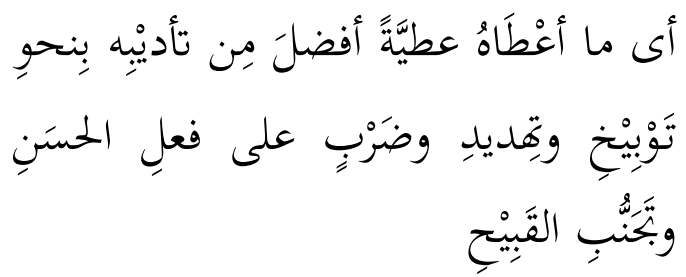

Maksudnya adalah tidaklah memberi orang tua kepada anaknya akan suatu pemberian yang lebih utama daripada pendidikan orang tua, dengan semacam taguran, ancaman dan memukul untuk berbuat kebaikan dan manjauhi hal yang buruk.

Penjelasan Syekh Nawawi terhadap hadits tersebut memberikan pemahaman akan pentingnya pemberian yang paling baik terhadap anaknya adalah pendidikan dengan metode pembelajaran berupa teguran, ancaman dan memukul untuk berbuat kebaikan dan manjauhi hal yang buruk. Bahkan Syekh Nawawi mengungkapkan bahwa pendidikan mampu mengangkat derajat seseorang sebagaimana ungkapan Syekh Nawawi :

$$
\begin{aligned}
& \text { فإنَ حُسنَ الأدَبِ يَرَفَعُ العَبْدَ الْمَمْلُوكِ إلى } \\
& \text { رَتبنَبَة الْمْلُوكِك }
\end{aligned}
$$

Karena sesungguhnya pendidikan yang baik dapat mengangkat seorang budak hamba sahaya kepada derajat para raja.

Demikianlah yang diungkap syekh Nawawi bahwa dengan pendidikan yang baik dapat mengangkat seorang budak kepada derajat raja. Demikian sesuai dengan firman Allah SWT :

$$
\begin{aligned}
& \text { يَرْفَعَع اللَّهُ الَِّْينَ آمَنُوا مِنْكُمْ وَالَّذِينَ أُوتُوا الْعِلْمَ } \\
& \text { دَرَجَاتِ }
\end{aligned}
$$

Niscaya Allah akan meninggikan orang-orang yang beriman di antaramu dan orang-orang yang diberi ilmu pengetahuan beberapa derajat. (QS. AlMujadilah 11) 
Selanjutnya Syekh Nawawi menguraikan hadits

$$
\begin{aligned}
& \text { وعن أبى ذرٍ رضي الله عنه قَالَ كنتُ جالسًا } \\
& \text { عند النبيّ (ص) وإِذا بِالَْسَنِ وَالُْسَسْنِنِ رضي } \\
& \text { الله عنهما رَكربًا على كَتْفِ جَدِّهِما رسولِ الله } \\
& \text { (ص) وهو يُحَدِّنُنَا فلما فرغ من حديثِه قال } \\
& \text { لمما انْزَلا يا أولادى لَّى }
\end{aligned}
$$

Dan diriwayatkan dari sayyidina Abu Dzarr radiyAllahu 'anhu, beliau berkata : "Saya pernah duduk di dekat Nabi SAW, tiba-tiba datang saat sayyidina hasan dan sayyidina Husein radiyAllahu 'anhuma, keduanya menaiki bau kakeknya, yaitu Rasulullah SAW, padahal beliau sedang berbicara kepada kami. Lalu tatkala beliau telah usai dari pembicaraannya, lalu beliau bersabda kepada keduanya: "Turunlah kalian berdua hai anak-anakku".

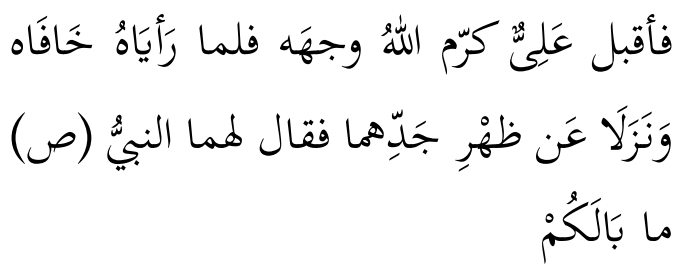

Lalu datanglah Ali kw, maka tatkala keduanya meliat ayahnya, maka keduanya merasa takut dan turun dari punggung kakeknya. Lalu Nabi SAW bersabda kepada keduanya: "Apa yang terjadi pada kalian?"

$$
\text { قالا خِفْنَا من أبِينًا }
$$

Keduanya berkata: "Kami takut dengan ayah kami”.

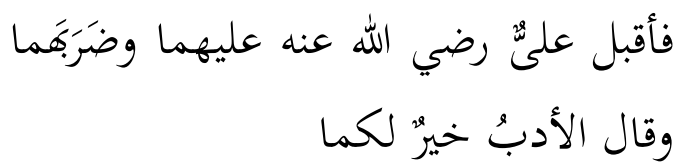

Lalu Ali ra, menghampiri keduanya dan memukul keduanya, sambil beliau berkata: "Kesopanan lebih baik bagi kalian berdua".

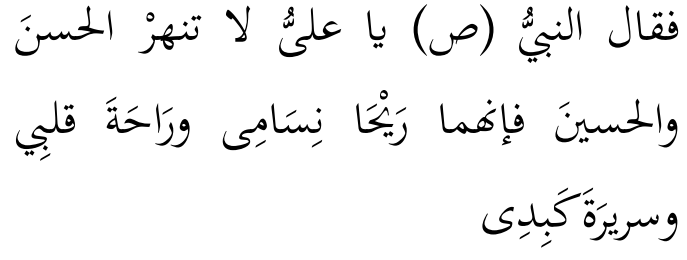

Lalu Nabi SAW bersabda: "Hai 'Ali, jangan engkau membentak Hasan dan Husein, karena sesungguhnya keduanya adalah pelega jiwaku, penyegar hatiku, dan kesayangan jantungku".

\section{فقال علىُّ كرم الله وجههه سَمْعًا وَطَاعَةً} saya ta'ati'.

Lalu Ali ra, "saya mendengar dan فَنَزَلَ جبريلُ وقال يا محمدُ الحُقٌ يقول أتُوُكَ<smiles>[3H][AsH2][AsH2]</smiles>

Lalu turunlah malaikat jibril, dan berkata: "Hai Muhammad, sang Maha Benar berfirman: "Biarkanlah Ali mendidik keduanya".

Dari keterangan diatas Syekh Nawawi menguraikan tentang kurikulum akhlaq dalam pendidikan teradap anakanaknya yakni Ali sedang mengajarkan terhadap anak-anaknya dengan mehampiri keduanya dan memukul keduanya sambil beliau berkata "Kesopanan lebih baik bagi kalian berdua".

Ada yang berpendapat bahwa pendidikan akhlaq dalam Islam dapat dimaknai sebagai latihan mental dan fisik. Latihan tersebut dapat menghasilkan manusia yang berbudaya tinggi untuk melaksanakan tugas kewajiban dan juga rasa tanggungjawab selaku hamba Allah SWT.

Pembinaan akhlaq merupakan bagian integral dan tak terpisahkan dalam dunia pendidikan karena tujuan pendidikan dalam Islam adalah menciptakan manusia yang beriman dan bertaqwa melalui ilmu pengetahuan, ketarampilan dan berperilaku sesuai dengan nilai-nilai Islam. Tujuan ini dapat diperoleh melalui proses pendidikan 
Islam sebagai cerminan karakter seorang Muslim. Kebaradaan pembinaan akhlaq ini ditujukan untuk mengarahkan potensipotensi baik yang ada pada diri setiap manusia agar selaras dengan fitrahnya selain itu juga untuk meminimalkan aspek-aspek buruknya (Syafri, 2014, hal. 67-70).

Para tokoh-tokoh pendidikan abad-abad lampau juga menekankan pentingnya pendidikan akhlaq sebagai salah satu landasan dasar dari sebuah proses pembentukan karakter dalam pendidikan. Ibnu Taimiyyah dan Imam al-Ghazali misalnya, meskipun hanya mengklasifikasikan pendidikan menjadi dua golongan namun pembahasan didalamnya termaswuk pendidikan iman, aklaq dan ukum. Begitu juga yang dilakukan Ibnu Khaldun yang meletakkan pendidikan keagamaan (iman) akhlaq, dan sosial kemasyarakatan dalam proses pendidikannya (Syafri, 2014, hal. 67-70).

Terkait pendidikan akhlaq, Syekh Nawawi melanjutkan dengan uraian dengan mengutip hadits

$$
\begin{aligned}
& \text { وقال عليه الصالاة والسلام من أرادَ أن يَرغُمَ }
\end{aligned}
$$

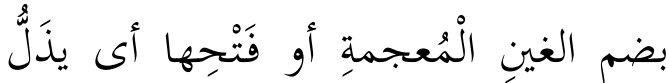

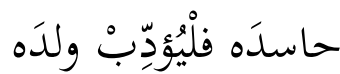

Dan telah bersabda Nabi SAW:

"Siapa saja yang hendak membuat jengkel, yakni menghinakan orang yang dengki kepadanya, maka endaklah ia mendidik anaknya".

$$
\begin{aligned}
& \text { وقال عليه الصالاة والسالام لأنْ يُوََدِبَ } \\
& \text { الوَّجُلُ وفن لفظٍ احدُكى }
\end{aligned}
$$

Dan nabi SAW bersabda: "pasti seseorang yang mendidik dan di dalam lafazh lain : ".. salah seorang dari kalian”.

$$
\text { ولََه أى يُعلِّمُهُ الآدابَ الشرعيَّةَ والْمَندوبَةَ }
$$
anaknya berbagai etika secara syari'at dan secara sunnah,

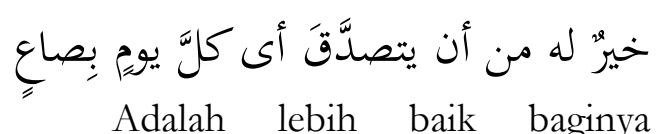
dibandingkan ia bersedekah, yakni setiap ari dengan satu sha'

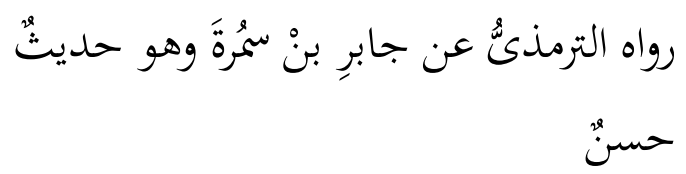

Hadits diriwayatkan oleh Imam al Tirmidzi dari Jabir ibn Samura, dan hadits tersebut adalah hasan.

قال المناويُّ لأنَّهُهـ إذا أدَّبَهَ صارت أفعالُه

من صدقاتِه الجاريةِ وصدقةُ الصاعِ ينقَطِعُ

ثَََكَابُها

Telah berkata Syekh al Manawiy: "Karena seseungguhnya apabila ia mendidik anaknya, maka jadila segala perbuatan anak itu termasuk dari sedekahnya yang mengalir terus, sedangkan sedekah satu sha' sudah terputus pahalanya".

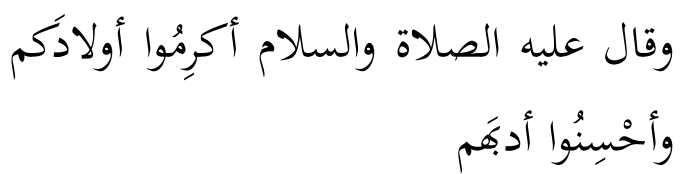

Dan Nabi SAW bersabda: "Muliakanlah oleh kalian anak-anak kalian, dan perbaguslah oleh kalian etikaetika mereka

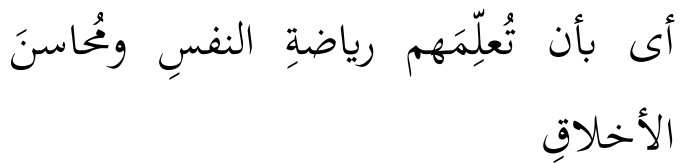

Yakni dengan kalian mengajari mereka latihan jiwa dan akhlaq-aklaq yang baik.

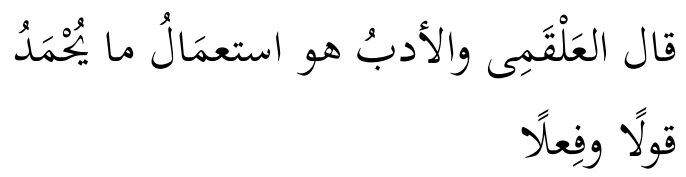

Telah berkata Syekh al 'Alqomiy: "Etika adalah penggunaan sesuatu yang terpuji, ucapan dan perbuata".

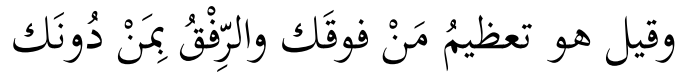


Dan dikatakan: "Etika adalah menghormati orang yang diatas dirimu dan berlaku lemah lembut kepada orang yang di bawahmu".

Demikianlah uraian Syekh Nawawi menekankan terhadap pentingnya pendidikan akhlaq pada anakanak, yakni mengajari anak dengan berbagai etikan secara syari'at dan secara sunnah bahkah pendidikan akhlaq terhadap anak itu lebih baik daripada sedekah satu sha' $(2,5 \mathrm{~kg})$ bahkan Syekh Nawawi mengutip Syekh al-Alqomiy bahwa etika adalah penggunaan sesuatu yang terpuji, ucapan, dan perbuatan. Memang demikian al-Quran pun mengajarkan sesuai dengan firman Allah SWT yang artinya "Amat besar kebencian disisi Allah bahwa kamu mengatakan apaapa yang tidak kamu kerjakan (QS. AlShaff (62) : 3), bahkan Syekh Nawawi mengutip bahwa etika itu adalah menghormati orang diatas dirimu dan berlaku lemah lembut kepada orang yang berada dibawahmu, hal ini sesuai dengan hadits Nabi SAW al Imam al Baihaqiy dalam kitabnya Syu'abul Iman meriwayatkan sebuah hadits:

$$
\begin{aligned}
& \text { أخبرنا أبو حمدٍٍ عبدُ اللهِ بنِ يوسف } \\
& \text { الأصبهابِنهُ نا أبوا سعيدِ بنِ الأعرابُِّ نا محمدُ } \\
& \text { بنُ إسماعيلَ نا يونسُ بنُ محمدٍ نا مَطرَّر } \\
& \text { الأعْنَقُ عن ثابتٍ عن أنسِ قال قال رسولُ } \\
& \text { الله (ص) يا أنس وَقِّرُوْا الكَبِيْرَ وارْحمْ الصغيرَ } \\
& \text { تُرافِقْنِى فن الجنَّةِ }
\end{aligned}
$$

Artinya: Telah mengkhabarkan kepada kami Abu Muhammad 'Abdullah ibn Yusuf al Ashbahaniy telah mengkhabarkan kepada kami Abu Sa'id ibn al-Arabiy telah mengkhabarkan kepada kami Muhammad ibn Ismail telah mengkhabarkan kepada kami Yusuf ibn Muhammad telah mengkhabarkan kepada kami Matha al A'raq dari tsabit dari Anas ia berkata Rasulullah SAW bersabda: "Wahai Anas hormatilah yang lebih tua dan sayangilah yang lebih muda, maka kau akan menemaniku di surga" (Syu'ab al-Imam No. 10979, n.d.).

Orang yang lebih tua adalah keberkahan untuk umat ini karena mereka telah banyak pengalaman lebih khusyu dalam beribadah mendalam ilmunya dan lebih matang dalam berfikir dan menimbang sesuatu serta tidak terburuburu dalam memutuskan sesuatu. Berbeda dengan para pemuda yang cenderung lebih emosional dan terburuburu dan masih kurang pengalaman.

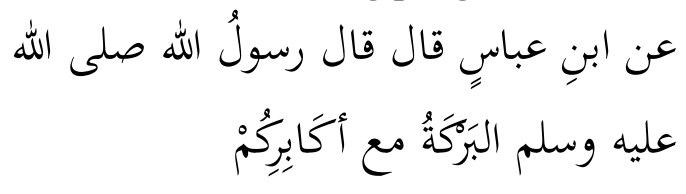

Artinya: Dari Ibn Abbas, ia berkata, Rasulullah SAW bersabda: "Keberkahan ada pada orang-orang tua dari kalian" (Mustadrak al Hakim 1/ 62, Shabib Ibn Hibban no. 559, dalam Mu'jam alAusath no. 8991, n.d.).

\section{Pendidikan Istri}

Syekh Nawawi dalam kitab 'Uqud al Lujjayn fi haqqi Zaujain menekankan perlu memberikan pendidikan kepada keluarga, baik anak ataupun istri agar terciptanya interaksi edukatif adalam lingkungan keluarga. Sebagimana Syekh Nawawi dalam menafsirkan QS. AtTahrim (66) ayat 6 :

$$
\begin{aligned}
& \text { (قال الله تعالى) فن سورةٍ التحريمع (يَا أَيْهَها }
\end{aligned}
$$

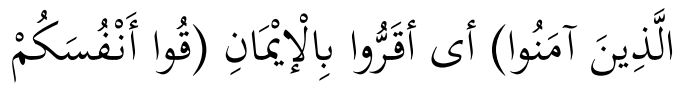

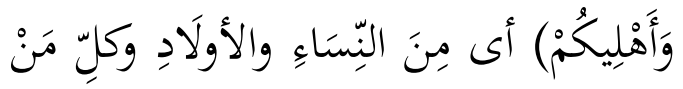

$$
\begin{aligned}
& \text { يدخُلو في هذا الاسم (نَارًا قال) تُرْهُمَانُ } \\
& \text { القرأنِ سيّدُنا عبدُ اللهِ (ابنُعباسِ) فن معنى } \\
& \text { ذلك (فَقِيّهُهْهم) أى عَلِّمُوْهم شَرَائعَ الإسالِح }
\end{aligned}
$$

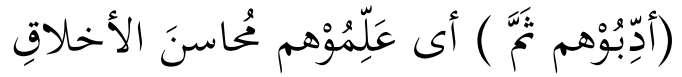




\section{وقيل أنَّ اشََّّ الناسِ عذابًا يومَ القيامِِِ مَنْ

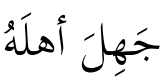

Artinya: Berfirman Allah ta'ala: dalam QS al-Tahrim (66) : 6, (Hai orangorang yang beriman) yakni yang telah mengatakan beriman (periharalah dirimu dan keluargamu) yakni istrimu, anakmu, dan setiap orang yang menggunakan namamu (dari apai neraka.... ) berkata menafsirkan al Qur'an Sayyidina 'Abdullah (Ibn 'Abbas) mengenai makna tersebut (maka berilah mereka pemahaman) yakni ajarkan mereka syari'at Islam (dan didiklah mereka tata krama) yakni mengajarkan mereka akhlak-akhlak yang baik. Dan disebutkan manusia yang paling berat siksaannya pada hari kiamat itu sebab menelantarkan pendidikan keluarganya.

Demikian Syekh Nawawi menguraikan berupa pentingnya memberikan pendidikan kepada istri dengan memberikan pelajaran-pelajaran Syari'at Islam dan akahlak. Karena wanita itu menjaga harta suami dan anakanaknya. Apakah dia melaksanakan dengan baik atau tidak.

Kitab 'Uqud al Lijjayn merupakan kitab rujukan bagi yang menginginkan keluarga sakinah berdasarkan al Qur'an, hadits, sejarah para tokoh terdahulu dan pendapat-pendapat ulama, yang terdiri dari empat pembahasan: Hak istri atas suami, Hak suami atas istri, Keutamaan wanita shalat di rumah, dan Larangan bagi laki-laki melihat wanita lain.

\section{Hak istri terhadap suami}

Perlakuan yang Baik terbadap istri

Syekh Nawawi menerangkan tentang keharusan bagi suami untuk mempergauli istri dengan cara yang makruf. Berikut yang disampaikan oleh syekh Nawawi dalam menafsirkan surat al-Nisa ayat 19 dan surat al Baqarah (2) ayat 228:

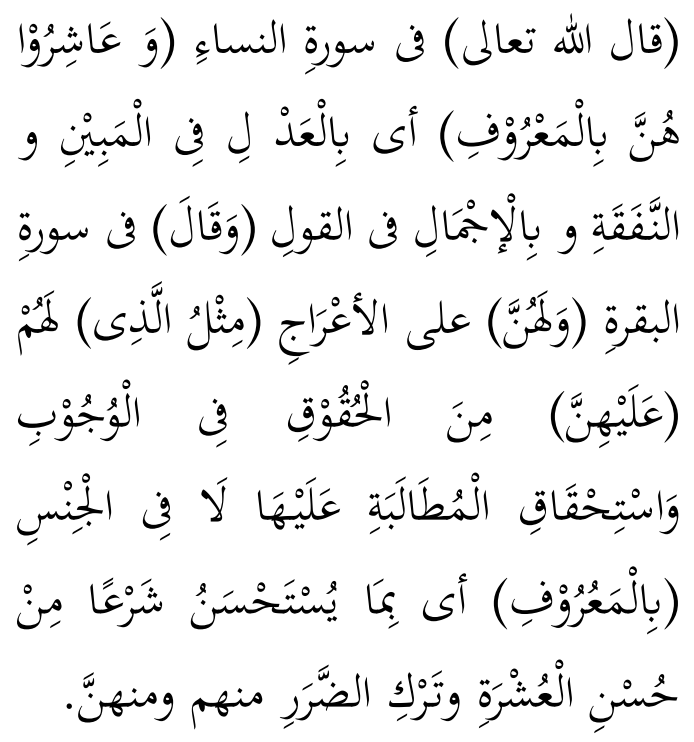

Artinya: (berfirman Allah Ta'ala) di dalam QS al-Nisa (4) ayat 19 (.... dan bergaullah dengan mereka secara patut....), maksudnya adalah dalam hal bermalam di rumah. Memberi nafkah, dan sopan bertutur kata. (dan Berfirman Allah, didalam QS 2 al-Baqarah : 228 (... dan para wanita) terhadap suami (mempunyai hak yang seimbang dengan kewajibannya) bagi para suami (atas para wanita) terhadap suami (atas para wanita) dari hak-hak yang wajib ditrunaikan dan tuntutan hak atas wanita bukan hanya pada jenis permintaannya (menurut cara yang makruf). Maksudnya cara yang makruf yaitu cara yang baik menurut ajaran agama seperti seperti pergaulan hidup yang baik diantara suami istri, dan meninggalkan hal yang membahayakan baik dari pihak suami meupun dari pihak istri.

Yang dimaksud kata patut dalam ayat diatas yaitu pertama, bijaksana. Maksudnya bahwa laki-laki harus biijaksana dalam mengatur waktu untuk istri. Demikian pula dalam hal menafkahi istri merupakan bagian dari hak istri. Hal lain yang terkait dengan masalah kepatutan disini adalah kehalusan dalam berbicara. (Busthami, 2000, hal. 11-12).

Bersikap lembut terbadap istri 
Syaikh Nawawi menjelaskan tentang isi dalam hadits diatas Nabi Muhammad SAW bermaksud memberikan perhatian kepada kaum muslimin agar mendengarkan apa yang diwasiatkan kepeda mereka dan selanjutnya melaksanakan wasiat itu. Dalam hal ini beliau menganjurkan agar kaum muslimin berhati lembut terhadap istri serta menunjukkan perilaku yang baik dalam bergaul dengan mereka. Itulah yang dimaksud dengan melakukan hal yang terbaik bagi wanita. Sebab, wasiat Nabi Muhammad saw dalam hadits diatas sudah barang tentu muncul karena faktor lemahnya wanita, termasuk didalamnya kebutuhan wanita itu sendiri terhadap keluhuran budi suami sebagai seorang yang menyediakan hal-hal yang menjadi keperluan mereka (Busthami, 2000, hal. 13-14).

Rasulullah yang mulia telah mempergauli istri-istrinya dengan baik. Secara sukarela, beliau membantu mereka menyelesaikan pekerjaan dan kewajiban mereka sehari-hari. 'Aisyah mengatakan : "Rasulullah dahulu sering membantu pekerjaan keluarganya. Beliau keluar hanya untuk shalat, jika waktu shalat telah datang" (Mahdi, 1999, hal. 144).

Disamping mempergauli istri dengan baik, suami juga wajib menjaga martabat dan kehormatan istrinya, mencegah istrinya jangan sampai hina, jangan sampai istrinya berkata jelek. Inilah kecemburuan yang disukai Allah swt. Nabi saw bersabda :

$$
\begin{aligned}
& \text { إن الله يغار و إن المؤمن يغار وغيره الله أن } \\
& \text { يأتي العبد ما حرم الله (رواه البخارى) }
\end{aligned}
$$

Artinya: "Allah cemburu dan manusia semburu, kecemburuan Allah adalah apabila ada hamba-Nya yang melanggar larangan-Nya". (HR. AlBukhari, t. t juz 3: 264) (Sa’id, 2002, hal. 163).

\section{Pentingnya Pendidikan Agama}

\section{Pentingnya pendidikan agama bagi anak}

Menurut (Tafsir, 1994, hal. 157) kunci pendidikan dalam rumah tangga sebenarnya terletak pada pendidikan agama pada anak. Karena pendidikan agamalah yang berperan besar dalam membentuk pandangan hidup seseorang. Menurutnya, ada dua arah mengenai kegunaan pendidikan agama dalam rumah tangga. Pertama, penanaman nilai dalam arti pandangan hidup, yang kelak mewarnai perkembangan jasmani dan akalnya. Kedua, penanaman sikap yang kelak menjadi basis dalam menghargai guru dan pengetahuan disekolah.

Pentingnya pendidikan anak sejalan dengan apa yang di uatarakan oleh Syekh Nawawi Tanqih al Qaul.

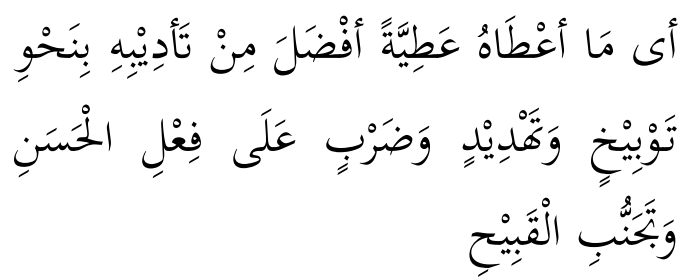

Maksudnya adalah tidaklah memberi orangtua kepada anaknya akan suatu pemberian yang lebih utama dari pada pendidikan orangtua, dengan semacam teguran, ancaman dan memukul untuk berbuat kebaikan dan menjauhi hal yang buruk,

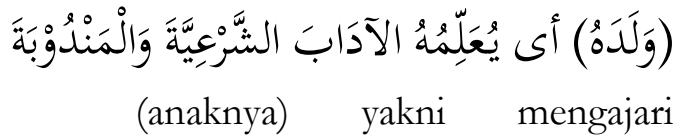
anaknya berbagai etika secara syariat dan secara sunnah,

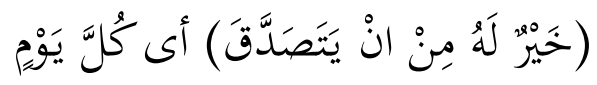

(adalah lebih baik baginya dibandingkan ia bersedekah) yakni setiap hari (dengan satu sha')

Penjelasan di atas, sesungguhnya sudah cukup untuk menjadi alasan tentang pentingnya pendidikan agama bagi anak, disamping telah banyak pula buku-buku, karya ilmiah maupun hasil penelitian yang dilakukan oleh para pakar pendidikan mengenai pendidikan agama dalam keluarga (rumah tangga) telah 
memberikan kesimpulan yang sama, bahwa pendidikan agama harus sudah diajarkan sejak dini kepada anak dalam keluarga atau rumah tangga.

\section{Aspek-aspek Pendidikan Agama yang diajarkan}

Ada beberapa aspek penting dari pendidikan agama Islam yang harus diajarkan kepada anak dalam keluarga. Aspek-aspek tersebut menurut Zakiyyah Darajat (dalam (Nata, 2001, hal. 292-293) sekurang-kurangnya mencakup pendidikan fisik, akal, agama (akidah dan agama), akhlak, kejiwaan, rasa keindahan, dan sosial kemasyarakatan.

Secara umum, pada mulanya aspek-aspek penting pendidikan agama Islam yang harus diajarkan pada anak di rumah meliputi mengajarkan mengaji (membaca al Qur'an), akidah, ibadah, dan akhlak. Namun seiring dengan perkembangan zaman dengan perkembangannya ilmu dan teknologi, aspek-aspek itu juga berkembang. Dengan memadukan semangat idealisme ke-Islaman dan realitas. Kehidupan yang selalu dinamis, aspek-aspek peting tersebut meliputi membaca al-Qur'an, menanamkan keyakinan (akidah) yang benar, membiasakan ibadah praktis, membentuk akhlak terpuji, mengajarkan semangat pluralitas, dan melatih keterampilan kerja. Masing-masing aspek tersebut akan dijelaskan sebagai berikut.

\section{Membaca al Qur'an} Nawawi

Hal ini sejalan pernyataan Syekh

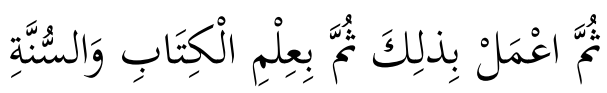

Kemudian lakukanlah semua hal itu, kemudian belajar ilmu-ilmu al-Qur'an dan sunnah (hadits-hadits Nabi saw).

\section{Menanamkan keyakinan ('Aqqîdah) yang Benar}

Aspek lain yang juga sangat penting untuk diajarkan kepada anak di rumah adalah masalah aqidah (keyakinan yang berkaitan dengan keimanan). Aqidah yang benar harus sudah ditanamkan kepada anak sejak dini agar kelak tidak mudah goyah, mudah berpaling dari keyakinan yang dapat merusak aqidahnya keIslamannya, bahkan menjadi murtad.

Menanamkan aqidah islamiyah yang benar tidaklah sebatas mengajarkan mengenai pengertian-pengertian (sebatas difinisi), tetapi lebih kepada isinya dan membangun kesadaran untuk mengamalkan dan menjaganya agar tidak terkotori oleh perbuatan-perbuatan terlarang, seperti takhayul, bid'âh, khurafat (TBC), dan bahkan syirik. Di rumah, anak cukup dikenalkan atau diajarkan mengenai 'a qî̀dah Islâmiyah yang dianut oleh sebagaian besar umat Islam di dunia, yaitu 'aqiîdah Islâmiyah dengan paham ahlu al sunnah wa al jamâ'ah.

Sementara aqidah dari pahampaham lainnya dapat saja diketahui anak di sekolah pada jenjang pendidikannya yang sudah memadai. Hal ini dilakukan agar anak tidak menjadi bingung atau terombang-ambing oleh ragam perbedaan pemikiran yang berkaitan dengan aqidah tersebut, apalagi jika sudah menyentuh pada pemikiran-pemikiran filsafatnya, seperti filsafat ketuhanan, dan lain sebagainya.

Syekh Nawawi menguraikan pendapatnya bahwa :

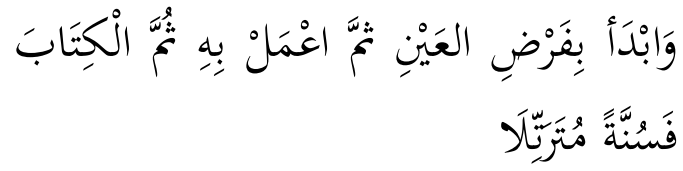

(Mulailah dengan ilmu fardu ' âin, kemudian kerjakanlah sesuai dengan ilmunya, kemudian al-Qur'an, lalu ilmu hadits, secara teratur)

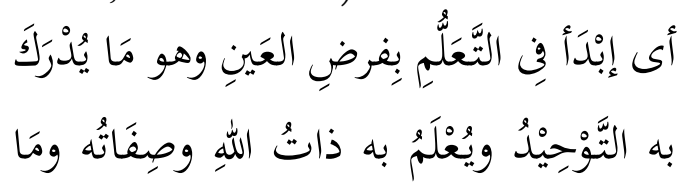




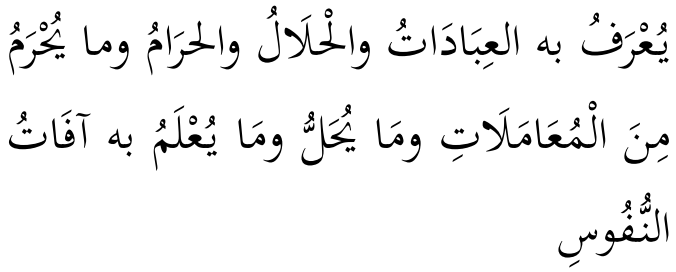

Maksudnya, mulailah dalam belajar dengan ilmu-ilmu fardu 'ain, yaitu (1) ilmu yang memahami masalah keEsaan Tuhan, (2) ilmu yang dapat mengetahui Zat Allah dan sifat-sifat-Nya, (3) ilmu yang dapat mengerti segala ibadah, segala yang halal dan haram, dan segala hal yang di haramkan dan di halalkan dalam berbisnis, dan (4) ilmu yang dapat mengetahui penyakit-penyakit jiwa.

Secara umum, lingkup aqidah yang perlu diajarkan kepada anak di rumah adalah yang berkaitan dengan masalah-masalah keimanan, yaitu keimanan kepada Allah swt.; keimanan kepada malaikat-Nya; keimanan kepada kitab-kitab-Nya; keimanan kepada para Nabi dan Rasul-Nya; keimanan kepada hari akhir (hari kemudian); dan keimanan kepada Qada' dan Qadar Allah swt. (ketetapan dan takdir Allah).

Ringkasnya, bahwa yang diajarkan dan ditanamkan kepada anak mengenai aqidah di rumah adalah hal-hal yang berkaitan dengan rukun iman, yang lebih bersifat sederhana dan mudah dipahami, dimengerti, dan diingat. Hal ini dimaksud sebagai pengetahuan awal atau dasar yang dapat dihubungkan dengan pengetahuan aqidah atau keimanan yang aka dipelajariya di sekolah, di masyarakat, seperti di masjid da majlis-majlis taklim dan lain sebagainya.

Secara sederhana yang diajarkan dan ditanamkan mengenai lingkup keimanan tersebut dapat dijabarkan sebagai berikut.

(a) Keimanan kepada Allah swt, yang meliputi keimanan atas Dzat-Nya yang Maha Kekal, keimanan atas sifatsifat-Nya yang Maha Sempurna dengan segala 'Asma (nama-nama)-Nya, dan keimanan atas perbuatan-Nya yang mutlak.

(b) Keimanan kepada para Malaikat-Nya yang meliputi asal kejadian dan sifat-sifat malaikat, nama-nama malaikat yang wajib diketahui, tugas masing-masing malaikat dan hikmah beriman kepada para malaikat Allah.

(c) Keimanan pada kitab-kitabNya yang meliputi nama-nama kitab-Nya (Taurat, Zabur, Injil, dan al Qur'an), para nabi yang menerima dan membawanya, kebenaran isi wayu dlaam kitab-Nya, dan disampaikan untuk umatnya, serta hikmah beriman kepada kitab-kitab Allah swt.

(d) Keimanan pada para nabi dan rasul-Nya yang meliputi nama-nama nabi dan rasul yang wajib diketahui, silsilah dan sejarah singkatnya, ajaran yang dibawanya, mushaf atau kitab yang dibawanya, mukjizat (kelebihan da keistimewaan sebagai tanda kenabian atau kerasulannya), zaman dan umat yang dihadapinya serta hikmah beriman kepada nabi dan rasul Allah swt.

(e) Keimanan kepada harei akhir (hari kemudian) yang meliputi namanama hari akhir (hari kemudian), adanya perhitungan amal perbuatan manusia (baik dan buruk), adanya pengadilan Allah swt., adanya pembalasan atas perbuatan mansia selama di dunia, adanya surga dan neraka, dan hikmah beriman kepada hari akhir (hari kemudian).

(f) Keimanan kepada Qada' dan Qadar Allah swt., yang meliputi pemahaman terhadap qada' dan qadar Allah, ikhtiar manusia dan do'a, kebebasan manusia dan kehendak Allah, dan hikmah beriman kepada qada' dan qadar Allah swt.

Untuk mengajarkan dan menanamkan hal-hal tersebut haruslah berdasarkan pengetahuan yang memadai dari sumber yang benar. Jika orangtua tidak memiliki kemampuan untuk itu, dapat mendelegasikannya kepada orang yang memang memiliki kemampuan 
untuk itu. Sementara orangtua, cukup memberikan contoh-contoh praktis yang dapat membantu anak untuk mudah memahaminya.

Di rumah, anak harus diyakinkan bahwa keimanan tidaklah sebatas keyakinan dalam hati, tetapi harus diakui secara lisan dan dibuktikan dengan perbuatan. Pengakuan secara lisan dan pembuktian melalui perbuatan akan terwujud dalam amal lisan dan perbuatan, baik dalam bentuk ibadah mahdhah, seperti syahadat, shalat, zakat, puasa, dan haji (rukun Islam), maupun dalam bentuk akhlak, perilaku, dan perbuatan kita sehari-hari. Smeuanya itu dilakukan berdasarkan keyakinan atau atas dasar keimanan yang benar.

Kepada anak juga harus dipahamkan secara bijak mengenai halhal yang dapat merusak keimanan (keyakinan), diantaranya perbuatan takhayul, bid'ah dan khurafat (TBC) terutama syirik.

\section{Membiasakan Ibadah Praktis}

Syekh Nawawi menyampaikan

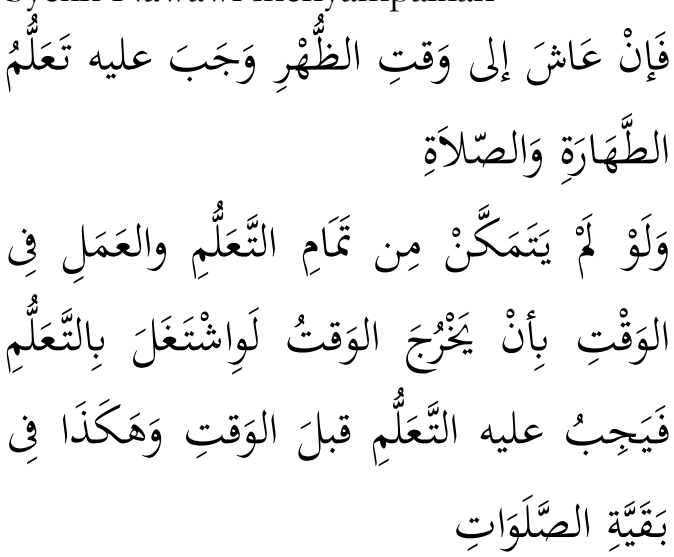

Lalu jika ia masih hidup sampai waktu Zhuhur, maka wajib baginya mempelajari bersuci dan shalat.

Jika ia tidak mungkin menyempurnakan pelajaran, dan mengamalkan di dalam waktu itu, sebab waktu shalat akan keluar, jika ia sibuk belajar, maka wajib baginya mempelajari sebelum waktu (shalat), dan demikian seterusnya pada shalat-shalat wajib yang lain.

Tugas orangtua adalah membimbing, mengawasi, dan mengawasi, dan membiasakan anak di rumah agar dapat, senang, dan istiqamah melakukan shalat sesuai ketentuannya. Sebelum orangtua mengajarkan anak shalat, yang tidak dapat dipisahkan adalah juga mengajarkan anak mengenai bersuci (thahârah) secara praktis, yaitu bagaimana ber-istinja', bersuci dari najis, bersuci dari hadas besar dan kecil, berwudlu dan bertayamum.

Melatih anak melaksanakan ibadah puasa

Membiasakan anak berzakat

Syekh Nawawi mengungkapkan bahwa.

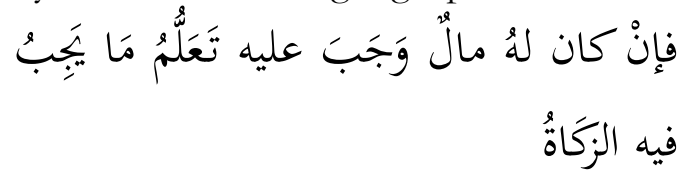

Lalu jika ia memiliki harta, maka wajib baginya mempelajari segala sesuatu yang wajib pada harta itu berupa zakat.

Mananamkan semangat anak untuk berbaji ke baitullah

Syekh Nawawi menyatakan :

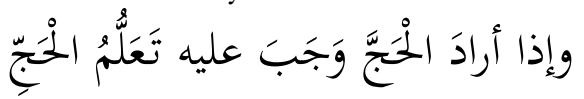

Apabila ia hendak pergi, maka wajib baginya mempelajari tentang haji.

Oleh karena itu, setiap Muslim harus memiliki cita-cita atau keinginan untuk dapat melaksanakan ibadah haji ke Baitullah di tanah suci Mekkah. Setiap orang yang memiliki keinginan kuat untuk melaksanakan haji, tentu akan berusaha menyaipkan dirinya agar memiliki kemampuan, baik secara ekonomi, yaitu memiliki keuangan yang cukup untuk pergi dan yang ditinggalkan, maupun kesehatan, dan pengetahuan yang diperlakukan untuk ibadah itu, sekalipun biasanya dibimbing oleh petugas haji. Kewajiban orangtua adalah menumbuhkan keinginan untuk haji pada anak-anaknya sehingga mereka terdorong untuk giat bekerja, belajar dan ingin 
tumbuh menjadi sehat agar kelak bisa pergi ke tanah suci menunaikan ibadah haji.

Pengetahuan mengenai ibadah haji, biasanya mereka dapati dari pendidikan agama di sekolah, bahkan di tingkat pendidikan pra-sekolah atau taman kanak-kanak (TK) Islam, di musim atau di bulan haji juga dilaksanakan manasik haji untuk anak-anak TK sambil menyaksikan praktik penyembelihan hewan kurban. Dengan demikian, tugas orangtua cukuplah sebatas menumbuhkan semangat dan keinginan anak-anaknya agar suatu saat kelak mereka mau menunaikan ibadah haji.

Pembentukan Akblak Terpuji

Syekh Nawawi menyatakan:

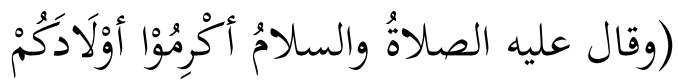
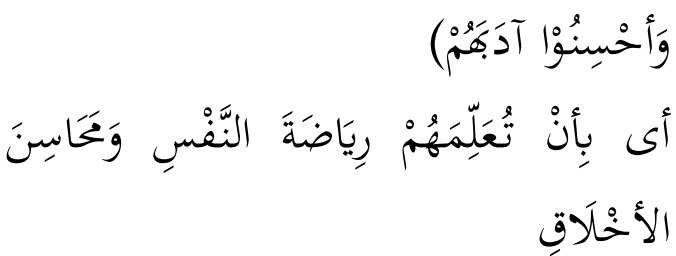

قال العَلْقَمِيُّ وَالأدَبُ هو استِعْمَالُ ما يُجحمَدُ

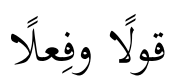

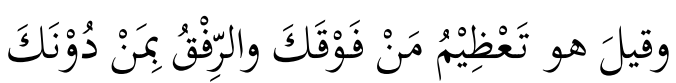

(Dan telah bersabda Nabi 'alaibish shalatu was salam: "Muliakanlah oleh kalian anak-anak kalian, dan perbaguslah oleh kalian etika-etika mereka")

Yakni dengan kalian mengajari mereka latihan jiwa dan akhlak-akhlak yang baik.

Telah berkata Syekh al-'Alqamiy: "Etika adalah penggunaan sesuatu yang terpuji, ucapan dan perbuatan".

Dan dikatakan (oleh satu pendapat): "Etika adalah menghormati orang yang di atas dirimu dan berlaku lemah lembut kepada orang yang di bawahmu".

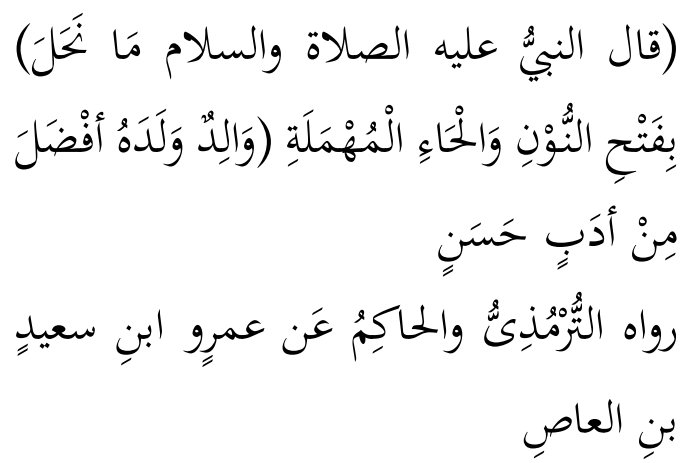

(Dan telah bersabda Nabi 'alaibi al shalatu wa al salâm: "Tidaklah memberi) (kalian nahalu) dengan fathaha nun dan $\underline{h}$ a yang tidak bertitik, (orang tua kepada anaknya akan sesuatu yang lebih utama dibandingkan pendidikan pekerti yang baik").

Hadits diriwayatkan oleh Imam Turmudzi dan Imam Hakim dari Sayyidina 'Amru bin Sa'id bin al-'Ash.

Memberikan Pendidikan seks

Syekh Nawawi mengutip hadits

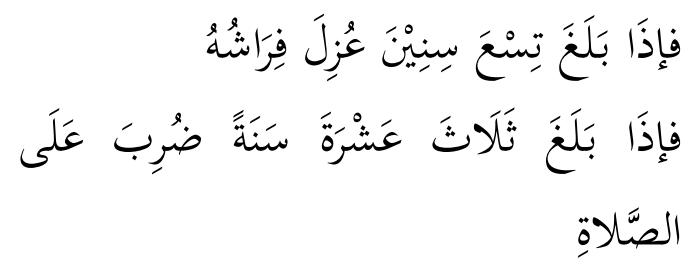

فإِذا بلغ سِتَّ عَشْرَةَ سَنَةً زَوَّجَهُ أبُوهُ

Artinya: Lalu apabila ia telah mencapai usia sembilan tahun, maka dipisahkan tempat tidurnya

Lalu apabila ia telah mencapai usia tiga belas tahun, maka ia dipukul atas (meninggalkan) shalat.

Lalu apabila ia telah mencapai usia enam belas tahun, maka ayahnya mengawinkannya.

\section{Pendidikan ekonomi dan Bisnis}

Syekh Nawawi mengungkapkan:

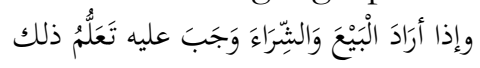

Dan apabila ia hendak jual-beli, maka wajib baginya mempelajari tentang hal itu.

\section{KESIMPULAN}


Konsep Tujuan Pendidikan Menurut Syekh Nawawi

Keluarga sebagaimana yang telah dipaparkan sebelumnya bahwa keluarga merupakn pilar terpenting dalam membangun sebuah perdaaban ummat manusia oleh karena nya maka di perlukan suatu konsep tujuan yang jelas agar seluruh perbuatan dan tingkahlaku dalam suatu keluarga memilki arah yang jelas sesuai dengan cita-cita semangat membangun bahtera rumah tangga.

Cara pandang seseorang akan menetukan tindak tanduk dalan melakukan suatu perbuatan dan cita-cita sehingga menghasilkan generasi terbaik maka kita harus memilki cara pandang Islam untuk tercapaiya harapan tersebut. Islam sebagai agama yang kita yakini bahwa Islam merupakan agama yang komprehensif yang mengatur sendi-sendi kehidupan manusia termasuk di dalamnya bagaima menciptakan keluarga yang berkualitas sesuai dengan tuntutan ajaran agama maka dengan hal ini kita patut mengetahui tujuan pendidikan keluarga untuk selanjutnya diamalkan sehari-hari.

Pemikiran Syekh Nawawi Al Bantani patut kita kaji untuk diamalkan karena Syekh Nawawi merupakah ulama yang sangat ahli di bidangn Al Quran Hadis ikih dan ilmu-ilmu keislaman lainnyadan memiliki pengaruh yang luar biasa di tanah air khususnya kalangan dunia pesantren. Menurut Syekh Nawawi bahwa harus melakukan pendidikan dengan kurikulum pendidikan adab/ akhlak karena memang manusia yang paling berat siksaannya pada hari kiamat adalah sebab menelantarkan pendidikan keluarganya oleh karenanya secara ringkas bahkan Syekh Nawawi menuturka agar tercapai tujuan pendidikan yakni menjadikan pribadi yang saleh-salehah maka harus dihindarkan tergesa-gesa mencari dunia, meninggalakan ibadah (fardu dan sunnah) dan lebih menyibukkan fardu kifayah dibandingkan fardu ain.

\section{Pendidikan Terbadap Anak}

Anak merupakan anugrah ALLAH SWT dan merupakan amanah yang harus di jaga sehingga anak akan di pertanggungjawabkan di akhirat kelak apakah anak sudah mendapatkan pendidikan yang sesuai dengan perintah agama yakni kurikulum yang pertama kali yang harus di ajarkan adalah shalat namun sebenarnya pengajaran ini di awal ketika baru lahir yakni diazankan.

Agar anak menjadi penyejuk hati dan orang tua berhasil mendidik anakanaknya dari segala macam kerusakan moral yang saat ini sudah sangat mudah diakses baik melalui media online (internet, Media Sosial) atapun media elektronik laiinya seperti televisi dan maraknya kasus kejahatan kejahatan yang dilakukan oleh anak-anak maka menjadi keharusan bagi orang tua untuk mendidik anak-anaknya dan dalam hal ini Syekh Nawawi mengingatkan kepada kita betapa pentingnya memberikan pendidikan terhadap anak karena menurut Syekh Nawawi bahwa tidaklah memberi orang tua kepada anaknya sesuatu pemberian yang lebih utama daripada pendidikan orang tua dengan metode yang ditawarkan yakni dengan teguran (nasehat/ konsul) dan Punishment karena pendiidkan yang baik akan menentukan karakter, sikap dan perilaku anaknya dimasa mendatang.

Bahkan Syekh Nawawi mengutip hadis Rasulullah menyebutkan fase usia pendidikan yakni usia 6 tahun, usia 9 tahun, usia 13 tahun dan usia 16 tahun bahkan kurikulum yang harus diajarkan yakni Bab Shalat hingga bab Nikah. demikianlah karena dengan pendidikan mampu mengangkat derajat seseorang. Demikian semoga arahan yang di uraikan syekh Nawawi dapat menjawab tantangan zaman saat ini tentang kerusakan mental 
anak didik dan melakukan revolusi mental berdasarkan nilai-nilai agama.

\section{Pendidikan pada Istri}

Suami sebagai kepala keluarga memiliki tanggungjawab yang besar untuk membimbing istri dan anak anaknya. Istri yang salehah merupakan keharusan yang harus dimiliki dalam suatu keluarga muslim karena istri kelak menjadi Madrasah awal bagi anakanaknya oleh karenanya pendidikan terhadap istri menjadi sebuah keharusan dengan situasi kondisi saat ini yang istri lebih mementingkan karir atau profesinya sehingga lupa untuk mendidik anakanaknya maka akan sangat berdampak buruk terhadap perkembangan spiritual/ perkembangan mental anak-anaknya oleh karenanya pandangan Syekh Nawawi akan pentingnya pendidikan istri harus benar-benar dikaji dan diamalkan.

Sebuah keluarga yang kuat manakala masing-masing pihak, suami dan istri memiliki komitmen yang kuat dalam membina rumah tangganya. Untuk memperkuat sebuah keluarga perlu diciptakan suatu situasi dan interaksi edukatif (mengandung nilai-nilai pendidikan) maka syekh Nawawi dalam menjelaskan surat at Tahrim ayat 6 intinya perintah untuk memberikan pelajaran terhadap anak dan istri dengan ilmu syariat Islam dan tata karma yakni mengajarkan akhlak yang baik dengan demikian kurikulum pendidikan keluraga secara garis besar yakni ilmu tentang hokum islam dan tata etika (adab) termasuk istri harus mengetahui hak dan kewajiban seorang istri dan perilaku yang seharusnya dilakukan bagi seorang istri. Dengan demikian akan tercipta keluarga sakinah, mawaddah dan warahmah. dan menghasilkan keturunan yang salehsalehah amiiin.

\section{DAFTAR PUSTAKA}

Al-Bantani, M. N. (n.d.-a). Syarah 'Uqud al Lujjayn. Surabaya: Pustaka Mampir.

Al-Bantani, M. N. (n.d.-b). Tanqih al-Qoul al-Hasists. Surabaya: Pustaka Mampir.

Busthami. (2000). No Title.

Chaidar. (1999). Sejarah Pujangga Islam Syekh Nawawi al Bantani. Pandeglang: Yayasan Pendidikan Pelajar al Haddad.

Langgulung, H. (2004). Manusia dan Pendidikan: Suatu Analisa Psikologis Filsafat dan Pendidikan. Jakarta: Al Husna Baru.

Mahdi, M. (1999). Pendidikan Keluarga dalam Islam. Semarang: Karya Toha Putra.

Mustadrak al Hakim 1/ 62, Shabih Ibn Hibban no. 559, dalam Mu'jam alAusath no. 8991. (n.d.).

Nata, A. (2001). Pemikiran Para Tokoh Pendidikan Islam. Jakarta: Rineka Cipta.

Nawawi, M. (n.d.). Salalim al-Fudala. Surabaya: Pustaka Mampir.

Rosyadi, R. (2014). Pendidikan Islam Dalam Perspektif Kebijakan Pendidikan Nasional. Bogor: IPB Press.

Sa'id, S. (2002). Tatanan Rumah Islami. Bandung: Robbani Press.

Salim, M. H. (2013). Pendidikan Agama dalam Keluarga. Yogyakarta: ArRuzz Media.

Siregar, M. (2007). Pemikiran Pendidikan Syekh Nawawi al Bantani. Yogyakarta: Datamedia.

Syafri, U. A. (2014). Pendidikan Karakter Berbasis al Qur'an. Depok: Raja Grafindo Persada.

Syu'ab al-Imam No. 10979. (n.d.).

Tafsir, A. (1994). Ilmu Pendidikan dalam Perspektif Islam. Bandung: Remaja Rosda Karya.

Terdapat dalam kitab Sunan at-Tirmidri, badits ke 1959, dalam Musnad Imam Ahmad Hadits ke 14856, dalam Jami'us shaghirjuz 2 buruf mim (HR. al Tirmidzi) dan dalam Kitab Syubul 
Asep Nuhdi/Ta'dib: Jurnal Pendidikan Islam, Vol. 9 No. 1 (2020) 77-95 ISSN 1411-8173 | E-ISSN 2528-5092

https://ejournal.unisba.ac.id/index.php/tadib/article/view/6219

Iman Imam Baihaqi juz VI hadits

Insani.

399 hadits ke 8. (n.d.).

Thohir, L., \& Natsir, M. (1999). Dakwah

dan Pemikirannya. Jakarta: Gema 